Article

\title{
Assessing the Environmental Sustainability of Electricity Generation in Turkey on a Life Cycle Basis
}

\author{
Burcin Atilgan and Adisa Azapagic * \\ Received: 23 October 2015; Accepted: 29 December 2015; Published: 7 January 2016 \\ Academic Editor: Vasilis Fthenakis \\ School of Chemical Engineering and Analytical Science, The University of Manchester, The Mill, Room C16, \\ Sackville Street, Manchester M13 9PL, UK; burcin.atilgan@manchester.ac.uk \\ * Correspondence: adisa.azapagic@manchester.ac.uk; Tel.: +44-0-161-306-4363
}

\begin{abstract}
Turkey's electricity mix is dominated by fossil fuels, but the country has ambitious future targets for renewable and nuclear energy. At present, environmental impacts of electricity generation in Turkey are unknown so this paper represents a first attempt to fill this knowledge gap. Taking a life cycle approach, the study considers eleven impacts from electricity generation over the period 1990-2014. All 516 power plants currently operational in Turkey are assessed: lignite, hard coal, natural gas, hydro, onshore wind and geothermal. The results show that the annual impacts from electricity have been going up steadily over the period, increasing by 2-9 times, with the global warming potential being higher by a factor of five. This is due to a four-fold increase in electricity demand and a growing share of fossil fuels. The impact trends per unit of electricity generated differ from those for the annual impacts, with only four impacts being higher today than in 1990, including the global warming potential. Most other impacts are lower from $35 \%$ to two times. These findings demonstrate the need for diversifying the electricity mix by increasing the share of domestically-abundant renewable resources, such as geothermal, wind, and solar energy.
\end{abstract}

Keywords: electricity generation; environmental impacts; life cycle assessment; Turkey

\section{Introduction}

With its young population, fast growing economy and industrialisation, Turkey has become one of the fastest growing energy markets in the world. Its energy demand has been increasing rapidly over the past few decades, rising almost six-fold in the period between 1970 and 2010 [1,2]. The demand for electricity has also followed this trend. In 2010, the total installed capacity of 49,524 MW generated $211,208 \mathrm{GWh}$ of electricity, four times more than in 1990 [3]. However, only $43 \%$ of the demand is met by domestic energy resources (lignite, hydropower, geothermal and wind) with the rest of electricity generated by imported fuels (hard coal and natural gas) [4]. As a result, Turkey has become dependent on other countries for the supplies of fuels, particularly natural gas, which provides $46.5 \%$ of electricity (see Figure 1). In 2010, around 98\% of the country's natural gas demand was met through imports, mainly from Russia [5]. At current production levels (730 million $\mathrm{m}^{3}$ in 2010), Turkey has the equivalent of only nine years of domestic gas reserves remaining [5]. There are currently 187 gas power plants with 18,213 MW of installed capacity, which, in 2010, generated 98,144 GWh [4]. The majority of the installations are combined cycle power plants [6].

The next most significant fuel is coal which supplies $26 \%$ of electricity [4]. Turkey has significant coal reserves with lignite being much more abundant than hard coal: 10.8 billion tonnes vs. 515 million tonnes of proven reserves, respectively [7]. However, most of Turkish lignite is of low quality with poor calorific value and high sulphur content. Hard coal is also of low grade, but of cokeable or semi-cokeable quality. In 2010, total coal production reached 73.4 Mt of which $69.7 \mathrm{Mt}$ was lignite, 
2.5 Mt hard coal and 1.2 Mt asphaltite [7]. By comparison, 24.3 Mt were imported, of which 60\% from Russia and Colombia and 40\% from the USA and South Africa [7]. There are 16 lignite and eight hard coal plants in Turkey, with the total installed capacity of 11,891 MW, which generated 55,046 GWh of electricity in 2010 [4]; the majority (65\%) of this was from the lignite plants. Around $85 \%$ of the capacity is based on pulverised coal and the rest on circulating fluidised bed installations.

In contrast to gas and coal, the contribution from oil power plants has been declining over the years, and today almost no oil power plants remain in Turkey, as most have been converted to natural gas combined cycle power plants [6].

The contribution of hydropower is close to that of coal, providing around a quarter of electricity (Figure 1). The theoretically-viable hydroelectric potential of Turkey is estimated at $433 \mathrm{TWh} /$ year [8]. Almost half of this is technically and nearly 30\% economically exploitable [8]. Currently, there are 55 reservoir and 205 run-of-river plants with the total installed capacity of 15,831 MW, generating on average $51,795 \mathrm{GWh}$ per year.

The only other sources of renewable energy available present in the electricity mix in Turkey are wind and geothermal, providing $1.4 \%$ and $0.3 \%$ of the total, respectively. Turkey has a good wind potential, estimated at 48,000 MW with an annual production capacity of $130 \mathrm{TWh} /$ year [9]. There are currently 39 onshore wind power plants with an installed capacity of $1320 \mathrm{MW}$ that produced $2916 \mathrm{GWh}$ in 2010. The capacity of the individual turbines varies from 0.85 to $3 \mathrm{MW}$. At present, there are no offshore wind turbines in Turkey.

Located on the Alpine-Himalayan tectonic belt, Turkey is one of the richest countries in the world in terms of geothermal energy resources, with an estimated capacity of 31,500 MW [9]. However, the majority of this $(88 \%)$ has the temperature below $200{ }^{\circ} \mathrm{C}$, which is less suitable for electricity generation (unless an organic Rankine cycle system is used) but is still useful for direct use as heat [10]. Thus, there are only six geothermal power plants in Turkey with the installed capacity of $94.2 \mathrm{MW}$ which generated 668 GWh in 2010 [3].

As a result of the high share of fossil fuels, the direct greenhouse gas (GHG) emissions from electricity (largely from burning fossil fuels) reached $99 \mathrm{Mt} \mathrm{CO}_{2}$-eq. in 2010, a quarter of the total national emissions in that year [11]. Since Turkey is a signatory to the Kyoto Protocol (Annex I), it is important that it identifies sustainable energy technologies suitable for the country to reduce the GHG emissions and other environmental impacts from the electricity sector. However, environmental impacts from the electricity sector in Turkey are currently unknown and there is no baseline to help the country identify the best way forward.

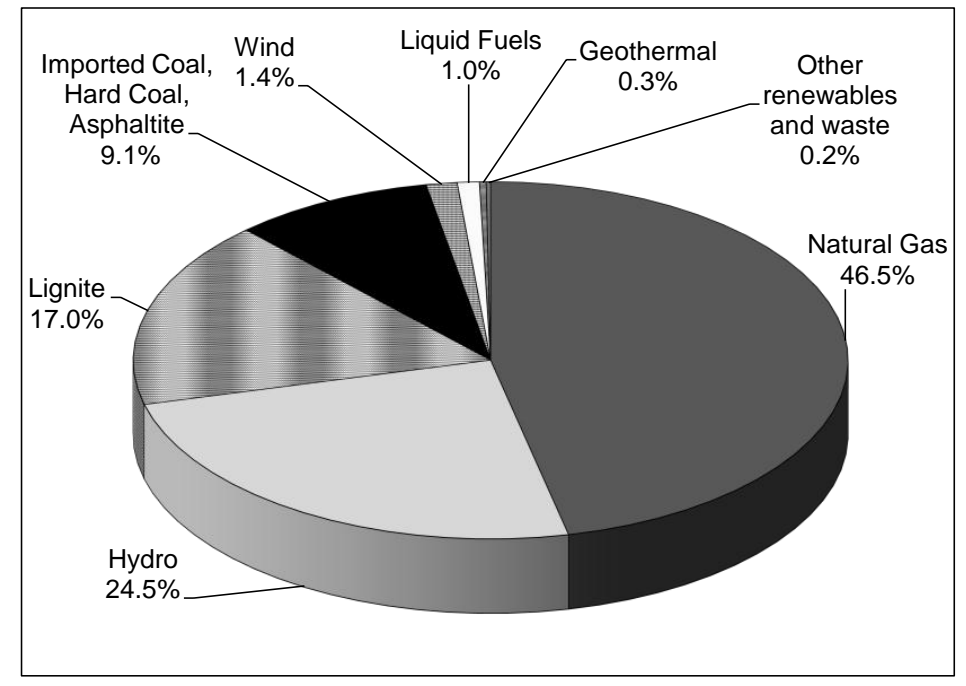

Figure 1. Share of different fuels in electricity generation in Turkey in 2010 [4]. 
Therefore, this paper sets out to estimate the environmental impacts of electricity in Turkey on a life cycle basis over the last 25 years (1990-2014). Although many life cycle assessment (LCA) studies of different electricity technologies have been carried out elsewhere, as far as the authors are aware, there are no such studies for Turkey. The only exception is the previous work by Atilgan and Azapagic [12,13], but that only considered electricity from individual technologies rather than the whole electricity supply mix which is the focus of this work. Therefore, this is the first study of its kind for Turkey and the findings will provide an insight into the past trends and current environmental impacts of electricity generation, helping to identify opportunities for improving the environmental sustainability of the sector. A further feature is that each of the 516 plants currently present in the Turkish electricity system have been considered individually. This has seldom been the case in other studies, which typically use average values for different technologies.

Some of the existing LCA studies relevant to the technologies present in Turkey's electricity mix are summarised in Table 1. The results from these studies are compared to the current study later in the paper (Section 3.1). As can be seen in the table, the scope varied across the studies, including the type of technologies and environmental impacts considered. All studies, however, considered GHG emissions and the related global warming potential. Most also considered eutrophication, acidification and photochemical smog, except Kannan, et al. [14] who considered the global warming potential and energy and Weisser [15] who focused on the global warming potential alone. Most studies used the Institute of Environmental Sciences (CML) 2001 method [16] to estimate the impacts. The same method has been applied in the current study, which considers 11 environmental categories, as discussed in the next sections.

\section{Methods}

The study has been carried out according to the LCA methodological guidelines in the International Organization for Standardization (ISO) 14040 and 14044 standards [17,18]. The LCA modelling has been carried out in GaBi v.6 [19].

Table 1. Some life cycle assessment (LCA) studies of electricity generation.

\begin{tabular}{|c|c|c|c|c|}
\hline Aim and Scope of the Study & Technologies & Country & Environmental Impacts & Reference \\
\hline $\begin{array}{l}\text { Life cycle energy use, GWP and } \\
\text { cost assessment of gas fired } \\
\text { combined cycle plant }\end{array}$ & Natural gas & Singapore & Global warming, energy use & [14] \\
\hline $\begin{array}{l}\text { Life cycle greenhouse gas } \\
\text { emissions from electric } \\
\text { supply technologies }\end{array}$ & $\begin{array}{l}\text { Lignite, hard coal, oil, natural } \\
\text { gas, nuclear, CCS, hydro, } \\
\text { wind, solar PV, biomass, } \\
\text { energy storage }\end{array}$ & Not specified & Global warming & [15] \\
\hline $\begin{array}{l}\text { Setting up life cycle models for the } \\
\text { environmental analysis of } \\
\text { hydropower generation, } \\
\text { considering technical and climatic } \\
\text { boundary conditions }\end{array}$ & $\begin{array}{l}\text { Run-of-river, storage and } \\
\text { pumped storage hydro }\end{array}$ & Germany & $\begin{array}{l}\text { Global warming, acidification, } \\
\text { eutrophication, photochemical } \\
\text { smog, energy demand }\end{array}$ & [20] \\
\hline $\begin{array}{l}\text { LCA of carbon dioxide capture } \\
\text { and storage from lignite } \\
\text { power plants }\end{array}$ & $\begin{array}{l}\text { Pulverised coal (PC), PC with } \\
\mathrm{CO}_{2} \text { capture, Integrated } \\
\text { gasification combined cycle } \\
\text { (IGCC), IGCC with } \mathrm{CO}_{2} \\
\text { capture, oxyfuel plant with } \\
\mathrm{CO}_{2} \text { capture }\end{array}$ & Germany & $\begin{array}{l}\text { Global warming, energy } \\
\text { demand, photochemical smog, } \\
\text { eutrophication, acidification }\end{array}$ & {$[21]$} \\
\hline $\begin{array}{c}\text { LCA of a } 2 \text { MW rated power } \\
\text { wind turbine }\end{array}$ & Onshore wind & Spain & $\begin{array}{l}\text { Global warming, resource } \\
\text { depletion, ecotoxicity, ozone } \\
\text { layer depletion, acidification, } \\
\text { eutrophication, photochemical } \\
\text { smog, human toxicity }\end{array}$ & [22] \\
\hline LCA of mini-hydropower plants & Run-of-river hydro & Thailand & $\begin{array}{l}\text { Global warming, resource } \\
\text { depletion, acidification, } \\
\text { human toxicity, photochemical } \\
\text { smog, water ecotoxicity }\end{array}$ & [23] \\
\hline
\end{tabular}


Table 1. Cont.

\begin{tabular}{|c|c|c|c|c|}
\hline Aim and Scope of the Study & Technologies & Country & Environmental Impacts & Reference \\
\hline LCA of electricity generation & $\begin{array}{l}\text { Nuclear, coal, natural gas, } \\
\text { oil, renewables }\end{array}$ & Mexico & $\begin{array}{l}\text { Global warming, ecotoxicity, } \\
\text { ozone layer depletion, } \\
\text { acidification, eutrophication, } \\
\text { photochemical smog, human } \\
\text { toxicity, resource depletion }\end{array}$ & {$[24]$} \\
\hline LCA of the wind turbines & Onshore wind & Spain & $\begin{array}{l}\text { Global warming, ecotoxicity, } \\
\text { ozone layer depletion, } \\
\text { acidification, eutrophication, } \\
\text { photochemical smog, human } \\
\text { toxicity, resource depletion }\end{array}$ & [25] \\
\hline LCA of a hydroelectric power & Run-of-river hydro & Thailand & $\begin{array}{l}\text { Global warming, ecotoxicity, } \\
\text { ozone layer depletion, } \\
\text { acidification, eutrophication, } \\
\text { photochemical smog, } \\
\text { resource depletion }\end{array}$ & [26] \\
\hline $\begin{array}{l}\text { Life cycle sustainability } \\
\text { assessment of } \\
\text { electricity generation }\end{array}$ & $\begin{array}{l}\text { Nuclear, coal, natural gas, } \\
\text { offshore wind, solar PV }\end{array}$ & UK & $\begin{array}{l}\text { Global warming, ozone layer } \\
\text { depletion, acidification, } \\
\text { eutrophication, photochemical } \\
\text { smog, land use, ecotoxicity, } \\
\text { human toxicity, } \\
\text { resource depletion }\end{array}$ & [27] \\
\hline $\begin{array}{l}\text { LCA of } 1 \mathrm{kWh} \text { generated by } \\
\text { a Gamesa onshore wind farm }\end{array}$ & Onshore wind & Europe & $\begin{array}{l}\text { Cumulative energy demand, } \\
\text { global warming, summer } \\
\text { smog, ecotoxicity, } \\
\text { eutrophication, acidification, } \\
\text { human toxicity, land use }\end{array}$ & {$[28]$} \\
\hline $\begin{array}{l}\text { Life cycle data for hydroelectric } \\
\text { generation at Embretsfoss } 4 \\
\text { power station }\end{array}$ & Run-of-river hydro & Norway & $\begin{array}{l}\text { Global warming, acidification, } \\
\text { eutrophication, photochemical } \\
\text { smog, ozone layer } \\
\text { depletion, waste }\end{array}$ & [29] \\
\hline $\begin{array}{l}\text { Life cycle data for hydroelectricity } \\
\text { from Trollheim power station }\end{array}$ & Reservoir hydro & Norway & $\begin{array}{l}\text { Global warming, acidification, } \\
\text { eutrophication, photochemical } \\
\text { smog, ozone layer } \\
\text { depletion, waste }\end{array}$ & {$[30]$} \\
\hline $\begin{array}{c}\text { Life cycle assessment of electricity } \\
\text { from an onshore V90-3.0 MW } \\
\text { wind plant }\end{array}$ & Onshore wind & Not specified & $\begin{array}{l}\text { Global warming, ecotoxicity, } \\
\text { ozone layer depletion, } \\
\text { acidification, eutrophication, } \\
\text { photochemical smog, human } \\
\text { toxicity, resource depletion }\end{array}$ & {$[31]$} \\
\hline $\begin{array}{l}\text { Life cycle assessment of } \\
\text { wind power }\end{array}$ & Onshore wind & Not specified & $\begin{array}{l}\text { Global warming, ecotoxicity, } \\
\text { ozone layer depletion, } \\
\text { acidification, eutrophication, } \\
\text { photochemical smog, human } \\
\text { toxicity, resource depletion }\end{array}$ & [32] \\
\hline LCA of a wind plant & Onshore wind & France & $\begin{array}{c}\text { Resource depletion, } \\
\text { acidification, eutrophication, } \\
\text { global warming, } \\
\text { photochemical smog }\end{array}$ & [33] \\
\hline
\end{tabular}

The CML 2001 method [16], November 2010 update, has been used to estimate the following impacts: abiotic depletion potential (ADP elements and fossil), acidification potential (AP), eutrophication potential (EP), fresh water aquatic ecotoxicity potential (FAETP), global warming potential (GWP), human toxicity potential (HTP), marine aquatic ecotoxicity potential (MAETP), ozone layer depletion potential (ODP), photochemical oxidants creation potential (POCP) and terrestrial ecotoxicity potential (TETP).

The goal of the study, key assumptions and data sources are detailed in the following sections.

\subsection{Goal and Scope Definition}

The goal of the study has been to estimate life cycle environmental impacts of electricity generation in Turkey and to identify improvement opportunities for the future. To enable that, the impacts of the 
individual power plants had to be estimated first. For these purposes, 2010 has been chosen as the base year because most complete data were available for the individual plants for that year. In addition to this, the impacts have been estimated for electricity generation over the past 25 years, covering the period from 1990 to 2014, to identify the impact trends and find out whether the electricity sector is becoming more or less environmentally sustainable.

The study is based on two functional units. The first is defined as "generation of $1 \mathrm{kWh}$ of electricity" to enable comparisons of the impacts for individual electricity technologies as well as for different electricity mixes for over the period. The second functional unit is defined as the "total annual electricity generation" to estimate the total annual impacts from electricity over the last 25 years.

As indicated in Figure 2, the study considers all the options present in the Turkish electricity mix: coal, gas, hydro (large- and small-scale reservoir, run-of-river), wind and geothermal. The scope is from "cradle to grave", comprising the extraction, processing and transport of fuels (where relevant) and raw materials as well as the construction, operation and decommissioning of power plants. Since the focus of the work is on electricity generation, its transmission, distribution and consumption are outside the system boundary.

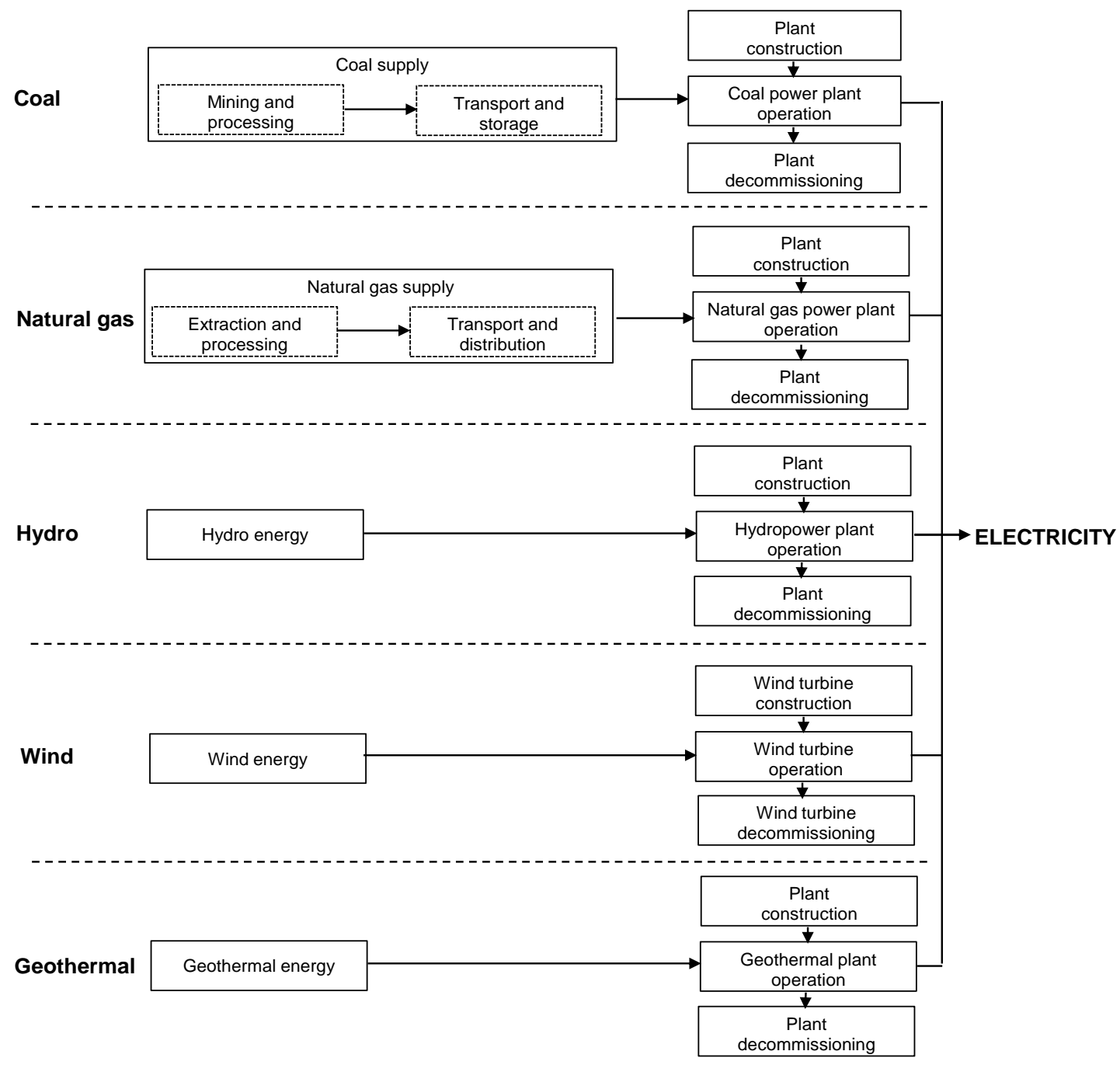

Figure 2. The life cycles of electricity from coal, natural gas, hydro, wind and geothermal power. 


\subsection{Inventory Data}

In 2010, 211,208 GWh of electricity were generated by a total of 516 power plants, specifically, by 16 lignite, eight hard coal, 187 gas, 55 reservoir and 205 run-of-river hydropower, 39 wind and six geothermal installations. All of these plants are considered in this study (see Table 2 and Supplementary information). The key assumptions are summarised in Tables 3 and 4 with further details provided below.

Table 2. Power plants in Turkey (2010).

\begin{tabular}{|c|c|c|c|}
\hline Type of Power Plant & $\begin{array}{c}\text { Number of } \\
\text { Plants }\end{array}$ & $\begin{array}{c}\text { Installed } \\
\text { Capacity (MW) }\end{array}$ & $\begin{array}{c}\text { Annual Generation } \\
\text { (GWh/yr) }\end{array}$ \\
\hline Lignite & 16 & 8140 & 35,942 \\
\hline Hard coal ${ }^{\mathrm{a}}$ & 8 & 3751 & 19,104 \\
\hline Natural gas & 187 & 18,213 & 98,144 \\
\hline $\begin{array}{c}\text { Large-reservoir } \\
\text { hydropower } \\
\text { (capacity > 500 MW) }\end{array}$ & 8 & 8459 & 30,583 \\
\hline $\begin{array}{c}\text { Small-reservoir } \\
\text { hydropower } \\
(\text { capacity < } 500 \mathrm{MW})\end{array}$ & 47 & 4608 & 13,885 \\
\hline $\begin{array}{l}\text { Run-of-river } \\
\text { hydropower }\end{array}$ & 205 & 2764 & 7327 \\
\hline Onshore wind & 39 & 1320 & 2916 \\
\hline Geothermal & 6 & 94 & 668 \\
\hline Total & 516 & $\begin{array}{c}47,349 \\
(49,524)^{b}\end{array}$ & $\begin{array}{c}208,569 \\
(211,208)^{c}\end{array}$ \\
\hline
\end{tabular}

a Hard coal type power plant includes hard coal, imported coal and asphaltite power plants in Turkey. ${ }^{\mathrm{b}}$ The total installed capacity in 2010 was 49,524 MW. The difference from the installed capacity shown in the table is due to multi-fuel, liquid fuel and other renewable-waste plants not included in the table. ${ }^{c}$ The total generation was $211,208 \mathrm{GWh}$. The difference from the generation shown in the table is due to liquid fuel and other renewable-waste plants not included in the table. However, the total actual electricity generation has been used to estimate the impacts from electricity mix.

Table 3. The amount of fuels used for electricity generation in 2010 [12].

\begin{tabular}{|c|c|c|c|c|c|}
\hline \multirow{2}{*}{ Domestic fuel } & \multirow{2}{*}{$\begin{array}{c}\begin{array}{l}\text { Natural Gas } \\
\left(\text { million } \mathrm{m}^{3}\right)\end{array} \\
-\end{array}$} & \multirow{2}{*}{$\begin{array}{c}\begin{array}{c}\text { Hard Coal } \\
\text { (million tonnes) }\end{array} \\
0.20\end{array}$} & \multirow{2}{*}{$\begin{array}{c}\begin{array}{c}\text { Lignite } \\
\text { (million tonnes) }\end{array} \\
55.89\end{array}$} & \multicolumn{2}{|c|}{$\begin{array}{l}\text { Transport Distances (km) } \\
\text { Gas }{ }^{\text {a }} \text { Hard Coal }{ }^{b}\end{array}$} \\
\hline & & & & - & - \\
\hline Imported fuel & & & & & \\
\hline Russia & 9921 & $4.45^{\mathrm{c}}$ & - & 5750 & 5000 \\
\hline Iran & 4383 & - & - & 2700 & - \\
\hline Azerbaijan & 2551 & - & - & 1150 & - \\
\hline Algeria & 2205 & - & - & 4000 & - \\
\hline Nigeria & 671 & - & - & 4500 & - \\
\hline USA & - & 1.48 & - & - & 10,500 \\
\hline South Africa & - & 1.48 & - & - & 13,000 \\
\hline Other & 1738 & - & - & 1750 & - \\
\hline Total & 21,469 & 7.61 & 55.89 & 19,850 & 28,500 \\
\hline
\end{tabular}

a Transport by pipeline. Total weighted average distance of $4000 \mathrm{~km}$ used for LCA modelling, taking into account the amounts of gas imported from each country as listed in the table. ${ }^{\mathrm{b}}$ Russia: $4500 \mathrm{~km}$ by rail, $500 \mathrm{~km}$ by shipping; USA: $1000 \mathrm{~km}$ by rail, $9500 \mathrm{~km}$ by shipping; South Africa: $500 \mathrm{~km}$ by rail, $12,500 \mathrm{~km}$ by shipping. ${ }^{c}$ This includes the amount of hard coal imported from Colombia but as there are no LCA data for the Colombian coal, the LCA impacts from the Russian coal have been used instead.

\subsubsection{Electricity from Fossil Fuels}

Detailed data have been available for each lignite and hard coal power plants so that each has been modelled separately based on the data in Tables S1 and S2 in Supplementary information. For the 
natural gas plants, data availability has been more limited. Therefore, an average efficiency of $55 \%$ has been assumed for all the gas plants; this matches the average efficiency of the combined cycle gas turbine (CCGT) plants for which the data have been available but also the efficiency of the plants in Turkey reported by IEA and NEA [34] as well as some other sources [35]. Specific data have not been available for the auto-producer plants; as mentioned earlier, they are not connected to the grid but generate electricity for own consumption. However, the total generation from these plants has been considered.

The data for the coal and natural gas power installations (Tables S1-S3 in Supplementary information) have been used together with the fuel composition data (Table 4) to estimate the emissions from each plant using GEMIS 4.8 software [36]. These have then been combined with the other inventory data in Tables 3 and 4 to estimate the life cycle impacts from the power plants in GaBi. The background life cycle inventory data have been sourced from Ecoinvent v2.2 [37] but have been adapted as far as possible to Turkey's conditions.

\subsubsection{Electricity from Renewables}

The data for the hydropower plants and onshore wind turbines are summarised in Tables 2 and 4; for details for the individual plants see Tables S4-S7 in Supplementary information. The background inventory data for hydropower have been sourced from the Ecoinvent v2.2 [37,38] and ESU [39] databases. Since the data for construction materials for reservoir plants in the databases correspond to a different size to the ones considered here, it has been necessary to apply some scaling of the impacts to reflect the difference in the size of the installations. Typically in LCA, this is carried out by assuming a linear relationship between the size of the plant and its impacts. However, in reality, the relationship is non-linear. To account for this, the "six-tenths" approach has been applied [40]. This method is typically used to estimate costs of different plant sizes accounting for the "economies of scale", i.e., larger plants cost less to build per unit of capacity than smaller installations. The same analogy has been applied to the impacts, which would also be lower per unit of installed capacity for bigger than smaller plants. Thus, the impacts have been scaled according to the following relationship:

$$
\mathrm{E}_{2}=\mathrm{E}_{1} \times\left(\frac{\mathrm{C}_{2}}{\mathrm{C}_{1}}\right)^{0.6}
$$

where:

$\mathrm{E}_{1}$ : environmental impacts of the larger plant

$\mathrm{E}_{2}$ : environmental impacts of the smaller plant

$\mathrm{C}_{1}$ : capacity of the larger plant

$\mathrm{C}_{2}$ : capacity of the smaller plant

0.6 : the "six-tenths" scaling factor.

The construction materials for the hydro plants are assumed to be transported for $200 \mathrm{~km}$ by rail and $100 \mathrm{~km}$ by lorry (see Table 4). At the end of its service life, the plants are dismantled and components are recycled using the assumed recycling rates given in Table 4.

The inventory data for onshore wind turbines have been sourced from [41] based on the Vestas V80 2 MW turbine. The size of the turbine has been scaled down from $2 \mathrm{MW}$ using Equation (1) to match the average turbine size in Turkey of $1.94 \mathrm{MW}$ (see Table 4). The construction materials are assumed to be transported $100 \mathrm{~km}$ by lorry and $100 \mathrm{~km}$ by rail. The turbines are imported into Turkey from Europe, assuming an average distance of $2000 \mathrm{~km}$ by rail and a further $150 \mathrm{~km}$ by lorry to the installation locations in Turkey. At the end of life, the turbine construction materials are recycled as specified in Table 4.

Detailed data for the geothermal plants have not been available so that the LCA data have been taken directly from the GaBi database [19]. The only dataset available is for a $30 \mathrm{MW}$ flash-steam plant with an annual electricity generation of $250 \mathrm{GWh}$. The data are aggregated so that it has not 
been possible to adapt them to Turkey-specific conditions. However, as geothermal power contributes only $0.3 \%$ of the total electricity (see Figure 1), this limitation is not deemed significant. Moreover, the database model is representative of the standard, widely-used type of geothermal plant.

The total annual environmental impacts for the base year have been calculated based on the impacts of all the options present in the Turkish electricity mix, their share in the electricity mix and the total electricity generation in 2010. The same approach has been applied across all the other years considered in this work.

To model the electricity mix in Turkey over the period, the following assumptions have been made:

- the contribution of the liquid-fuel power plants to the total generation of electricity is small and for simplicity has been substituted with the equivalent amount of electricity generated by the gas power plants;

- the data on the specific technologies for other renewables and waste have not been available. As their contribution to the total electricity generation is small, they have been substituted by small-reservoir hydropower.

It has also been assumed that there were no technology changes over the period considered, using the characteristics of technologies in 2010 to model the impacts for the previous years. This is arguably a reasonable assumption as fossil and hydro-technologies are well established and have long lifetimes so that no technological changes would be expected over the period. Wind and geothermal are less well established, but their contribution to the total generation in the earlier years was negligible $(<0.03 \%$ and $<0.1 \%$, respectively).

\section{Results and Discussion}

The results are given in Figures 3-9 and are discussed in the following sections, first for different electricity technologies, then for electricity in the base year (2010) and finally for electricity generation from 1990 to the present.

\subsection{Environmental Impacts of Different Electricity Technologies}

The life cycle environmental impacts of different electricity generation options in Turkey are compared in Figure 3 and in Tables S8-S18 in Supplementary information. The results show that coal is the worst performer for all the impact categories, except for the ODP, which is lower than for gas power because of leakages of halon 1211 and halon 1301 used as fire suppressants and coolants in the life cycle of gas. Wind power has the highest impacts among the renewable options, with nine out of 11 impacts higher than for hydropower and geothermal power. This is due to the impacts from the extraction and processing of the construction materials. Wind power also has the second highest ADP elements, after hard coal. On the other hand, its GWP is $88 \%$ lower than for geothermal power and $11 \%$ smaller than for large-reservoir hydropower. The AP of geothermal electricity is lower than lignite power and higher than any other power options considered in this study: almost all of the impact is due to the hydrogen sulphide emissions from geothermal steam to air.

\section{Comparison of Results with the Literature}

As far as the authors are aware, there are no other LCA studies of electricity technologies in Turkey, except the previously mentioned studies $[12,13]$. However, as discussed in the introduction, there are many studies of electricity technologies in other countries, which are compared to the results from the current study in Figures 4 and 5. As can be seen, a wide range of values has been reported in the literature across different impacts. This is primarily due to different assumptions, such as capacities and efficiencies, pollution control measures, fuel origin, plant lifetimes and, in the case of hydropower and wind, local water and wind characteristics and plant design. 
Table 4. Assumptions and summary of inventory data.

\begin{tabular}{|c|c|c|c|}
\hline Coal & Gas & Hydropower & Wind \\
\hline \multicolumn{4}{|l|}{ Mining and Processing } \\
\hline $\begin{array}{l}\text { Lignite: } \\
\text { - } \quad \text { Domestic lignite, open pit and } \\
\text { underground mining } \\
\text { - Composition }(\% \mathrm{w} / \mathrm{w})^{\mathrm{a}} \text { : sulphur: } \\
0.8 \%-4.5 \% \text {; ash: } 19 \%-40 \% \text {; water: } \\
20 \%-50 \% \\
\text { - } \mathrm{Net} \text { heating value }(\mathrm{NHV}) \text { : } \\
7.2-13.9 \mathrm{MJ} / \mathrm{kg}\end{array}$ & $\begin{array}{ll}\text { - } & \text { Composition (\% vol.) } \\
& \text { a } \\
\mathrm{C}_{1}: 94.7 \%-97.3 \% ; \mathrm{C}_{2}: 1-3.4 \% ; \\
\mathrm{C}_{3}: 0.3 \%-0.6 \% ; \mathrm{C}_{4}: 0.1 \%-0.4 \% ; \\
\mathrm{C}_{5+}: 0.02 \%-0.1 \% ; \mathrm{CO}_{2}: 0.06 \%-0.6 \% ; \\
\mathrm{N}_{2}: 0.1 \%-4.6 \% \\
\text { - } \quad \text { NHV: } 36.5-40.4 \mathrm{MJ} / \mathrm{kg} \\
\text { - Leakage during extraction: } 0.38 \%\end{array}$ & & \\
\hline $\begin{array}{l}\text { Hard coal: } \\
\text { - Domestic and imported, open pit and } \\
\text { underground mining } \\
\text { - Composition }(\% \mathrm{w} / \mathrm{w})^{\mathrm{a}} \text { : } \\
\text { sulphur: } 0.5 \%-0.9 \% \text {; ash: } 7 \%-11 \% \text {; } \\
\quad \text { water: } 4 \%-7 \% \\
\text { - NHV: } 27-27.5 \mathrm{MJ} / \mathrm{kg}\end{array}$ & & & \\
\hline \multicolumn{4}{|l|}{ Transport $^{b}$} \\
\hline $\begin{array}{l}\text { Lignite: } \\
\text { - Power plants adjacent to the mine } \\
\text { Hard coal: } \\
\text { - Russia: Freight train }(4500 \mathrm{~km}) \text {; freight } \\
\text { - } \quad \text { USip }(500 \mathrm{~km}) \\
\text { - ship }(9500 \mathrm{~km}) \\
\text { - South Africa: Freight train }(500 \mathrm{~km}) \text {; } \\
\text { freight ship }(12,500 \mathrm{~km})\end{array}$ & $\begin{array}{l}\text { - Pipeline: Russia: } 5750 \text { km; } \\
\text { Iran: } 2700 \text { km; Azerbaijan: } 1150 \text { km; } \\
\text { Nigeria: } 4000 \text { km; Other: } 4500 \text { km }\end{array}$ & $\begin{array}{l}\text { - Construction materials }{ }^{\text {c: }} \text { Freight train: } \\
200 \mathrm{~km} \text {; Lorry > } 16 \text { tonne: } 100 \mathrm{~km}\end{array}$ & $\begin{array}{l}\text { - Construction materials: Freight train: } \\
100 \mathrm{~km} \text {; Lorry > } 16 \text { tonne: } 100 \mathrm{~km} \\
\text { Turbine: Freight train: } 2000 \mathrm{~km} \text {; } \\
\text { Lorry > } 16 \text { tonne: } 150 \mathrm{~km} \\
\text { Maintenance: Passenger car: } \\
100 \text { p.km/year }\end{array}$ \\
\hline
\end{tabular}


Table 4. Cont.

\begin{tabular}{|c|c|c|c|}
\hline Coal & Gas & Hydropower & Wind \\
\hline \multicolumn{4}{|l|}{ Plant Construction } \\
\hline $\begin{array}{l}\text { - Lifetime: } 30 \text { years }{ }^{\mathrm{d}} \\
\text { Lignite: } \\
\text { - Data from Ecoinvent }{ }^{\mathrm{e}} \text { based on } \\
\text { average size of the plant of } 380 \mathrm{MW} \text { (a } \\
\text { mix of } 500 \mathrm{MW} \text { and } 100 \mathrm{MW} \text { plants in } \\
\text { a } 70: 30 \text { ratio) } \\
\text { Hard coal: } \\
\text { - Data from Ecoinvent }{ }^{\mathrm{e}} \text { based on } \\
\text { average size of the plant of } 460 \mathrm{MW} \\
\text { (a mix of } 500 \mathrm{MW} \text { and } 100 \mathrm{MW} \text { plants } \\
\text { at the } 90: 10 \text { ratio) }\end{array}$ & $\begin{array}{l}\text { - Lifetime: } 25 \text { years }{ }^{\mathrm{d}} \\
\text { Data from Ecoinvent assuming } \\
400 \mathrm{MW} \text { plant }\end{array}$ & $\begin{array}{l}\text { Large reservoir: } \\
\text { - } \quad \text { Life time: } 150 \text { years e,f } \\
\text { - } \quad \text { Large reservoir } \\
\text { - } \quad \text { Data based on Ecoinvent } \mathrm{e}, \mathrm{g} \text { with } \\
\text { average size of } 175.6 \mathrm{MW} \text { plant and } \\
\text { scaled up to } 1057 \mathrm{MW} \text { plant } \\
\text { Small reservoir: } \\
\text { - } \quad \text { Data based on ESU }{ }^{\mathrm{f}} \text { with average size } \\
\text { of } 95 \mathrm{MW} \text { plant and scaled up to } \\
\quad 98 \mathrm{MW} \text { plant } \\
\text { Run-of-river: } \\
\text { - Life time: } 80 \text { years }{ }^{\text {e,f }} \text { Data based on } \\
\text { ESU f for the average size of } 8.6 \mathrm{MW} \\
\text { plant and scaled up to } 13.5 \mathrm{MW} \text { plant }\end{array}$ & $\begin{array}{l}\text { - Lifetime: } 40 \text { years for fixed parts and } \\
20 \text { years for moving parts } \mathrm{e} \\
\text { - Number of turbines: } 682 \\
\text { Data based on the average size of } 2 \mathrm{MW} \\
\text { turbine } \mathrm{h} \text { and scaled down to the average } \\
\text { size of } 1.94 \mathrm{MW}\end{array}$ \\
\hline
\end{tabular}

\section{Plant Operation}

- $\quad$ See Table 3 for details

Lignite:

- Average water use: $37.3 \mathrm{~kg} / \mathrm{kWh}$

Hard coal:

- Average water use: $32.7 \mathrm{~kg} / \mathrm{kWh}$

\section{Large reservoir:}

- All plants assumed to be CCGT with efficiency of $55 \%$

- Average water use: $3.4 \mathrm{~kg} / \mathrm{kWh}$
- Lubricating

Small reservoir

- $\quad$ Lubricating oil: $0.03 \mathrm{mg} / \mathrm{kWh}$

Run-of-river:

- Lubricating oil: $0.12 \mathrm{mg} / \mathrm{kWh}$

\section{Plant Decommissioning}

- Metals: $50 \%$ recycled, $50 \%$ landfilled

- Concrete: $50 \%$ recycled, $50 \%$ landfilled

- Plastics: $20 \%$ recycled, $80 \%$ landfilled
- Metals: $50 \%$ recycled, $50 \%$ landfilled

- Concrete: $50 \%$ recycled, $50 \%$ landfilled

- Plastics: $20 \%$ recycled, $80 \%$ landfilled
- Metals: $50 \%$ recycled, $50 \%$ landfilled - Metals: $50 \%$ recycled, $50 \%$ landfilled

Concrete: $50 \%$ recycled, $50 \%$ landfilled - Concrete: $50 \%$ recycled, $50 \%$ landfilled

- Plastics: $20 \%$ recycled, $80 \%$ landfilled - Plastics: $20 \%$ recycled, $80 \%$ landfilled

${ }^{a}$ Based on data from different mines and countries. ${ }^{b}$ Estimated by using online mapping. ${ }^{c}$ It is assumed that gravel is extracted at the construction site. ${ }^{d}$ Source: [42]. ${ }^{\text {e }}$ Source: [37].

f Source: [39]. g Source: [38]. ${ }^{\text {h }}$ Source: [41]. ${ }^{\mathrm{i}}$ The system has been credited for recycling. The recycling rates are assumed due to a lack of data. 


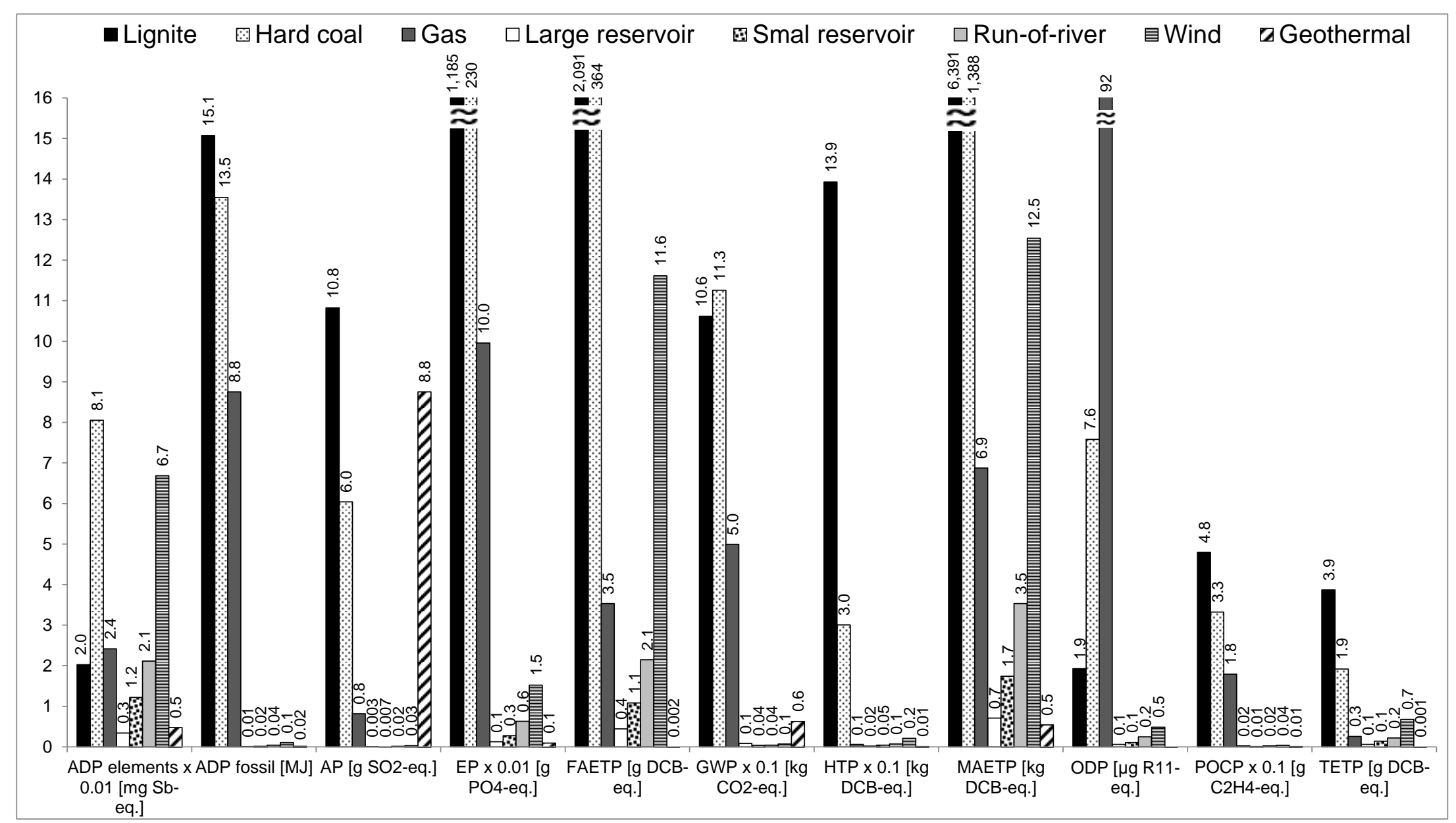

Figure 3. Environmental impacts for different electricity options in Turkey. [All impacts expressed per kWh of electricity generated. The values shown on top of each bar represent the total impact after the recycling credits for the plant construction materials have been taken into account. Some values have been rounded off and may not correspond exactly to those quoted in the text. ADP: Abiotic depletion of elements; ADP fossil: Abiotic depletion of fossil; AP: Acidification potential; EP: Eutrophication potential; FAETP: Fresh water aquatic ecotoxicity potential; GWP: Global warming potential; HTP: Human toxicity potential; MAETP: Marine aquatic ecotoxicity potential; ODP: Ozone layer depletion potential; POCP: Photochemical oxidants creation potential; TETP: Terrestrial ecotoxicity potential.]. 


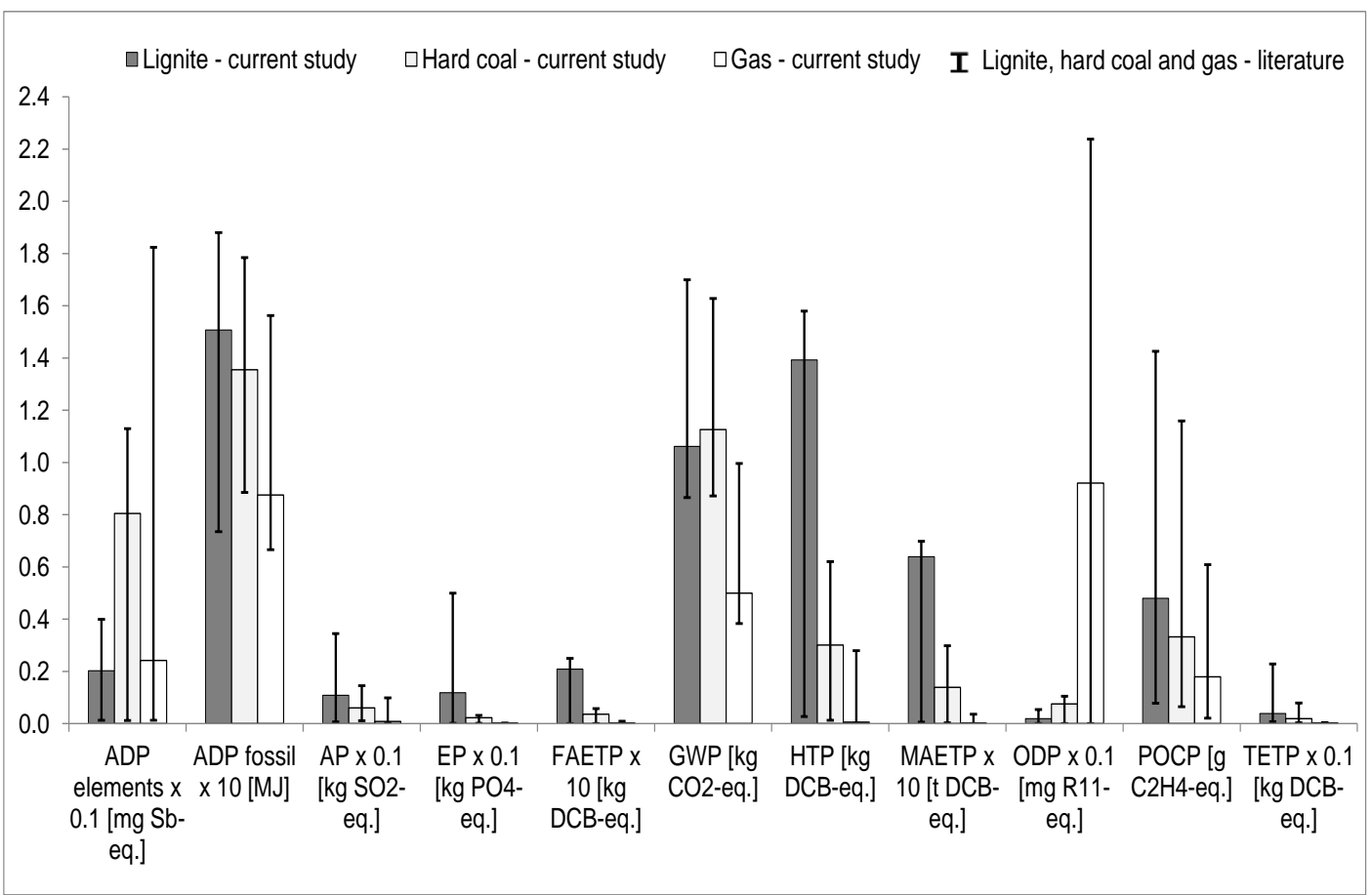

Figure 4. Comparison of the results from current study with literature for coal and gas. [All impacts expressed per kWh of electricity generated. Literature data for lignite from [15,19,21,43]; for hard coal from [19,27,43]; for natural gas from [14,15,19,24,27,43]. All impacts estimated using the CML 2001 method. For impacts nomenclature, see Figure 3.].

Nevertheless, all the impacts estimated in this study for lignite and hard coal power are well within the ranges reported in the literature (Figure 4). For example, for lignite electricity, the GWP falls between 866 and $1700 \mathrm{~g} \mathrm{CO}_{2}$-eq. $/ \mathrm{kWh}$, which compares well with the estimate in this study of $1062 \mathrm{~g}$ $\mathrm{CO}_{2}$-eq. $/ \mathrm{kWh}$. For hard coal, the GWP in the literature ranges between 872 and $1628 \mathrm{~g} \mathrm{CO}_{2}$-eq. $/ \mathrm{kWh}$ so that the value of $1126 \mathrm{~g} \mathrm{CO}_{2}$-eq. $/ \mathrm{kWh}$ obtained in the current study is around the middle of the range. A good agreement of the results is also found for gas electricity. For instance, the GWP reported in the literature is between 383 and $996 \mathrm{~g} \mathrm{CO}_{2}$-eq. $/ \mathrm{kWh}$, and, in this work, it is estimated at $499 \mathrm{~g}$ $\mathrm{CO}_{2}$-eq./kWh.

There are only four LCA studies of reservoir hydropower plants so that comparison with the literature is limited. As shown in Figure 5, the results for the GWP, AP, EP, ODP, POCP and TETP are comparable to the lower values reported in the literature. For example, the GWP falls between 2.7 and $11.6 \mathrm{~g} \mathrm{CO}_{2}$-eq. $/ \mathrm{kWh}$ in the literature, which compares well to this study's estimate of $6.9 \mathrm{~g}$ $\mathrm{CO}_{2}$-eq. $/ \mathrm{kWh}$ for reservoir hydropower. On the other hand, the results for the ADP elements and fossil, FAETP, HTP and MAETP are below the range of values in the literature. One of the reasons for this could be the very different size of large and small scale plants which are not distinguished in the literature.

All the impacts estimated in this study for run-of-river hydropower and wind electricity are well within the ranges reported by other authors (Figure 5). For example, the GWP for run-of-river hydropower is between 0.3 and $5.2 \mathrm{~g} \mathrm{CO}_{2}$-eq. $/ \mathrm{kWh}$, which compares well to the value of $4.1 \mathrm{~g}$ $\mathrm{CO}_{2}$-eq. $/ \mathrm{kWh}$ obtained in the current study. For onshore wind, the GWP ranges from 6.2 to $31 \mathrm{~g}$ $\mathrm{CO}_{2}$-eq. $/ \mathrm{kWh}$, and the estimate in the present work is $7.3 \mathrm{~g} \mathrm{CO}_{2}$-eq. $/ \mathrm{kWh}$. 


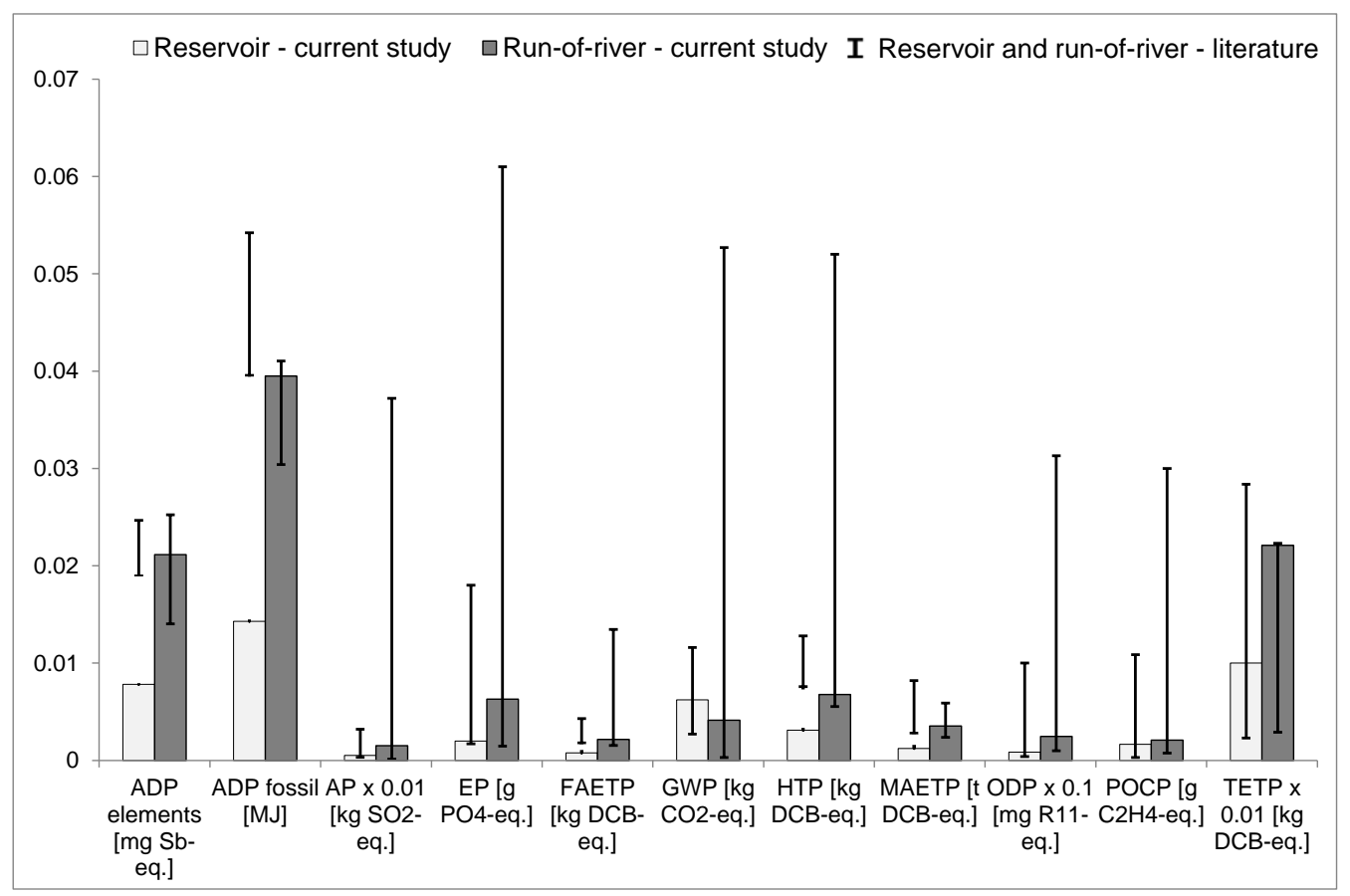

(a)

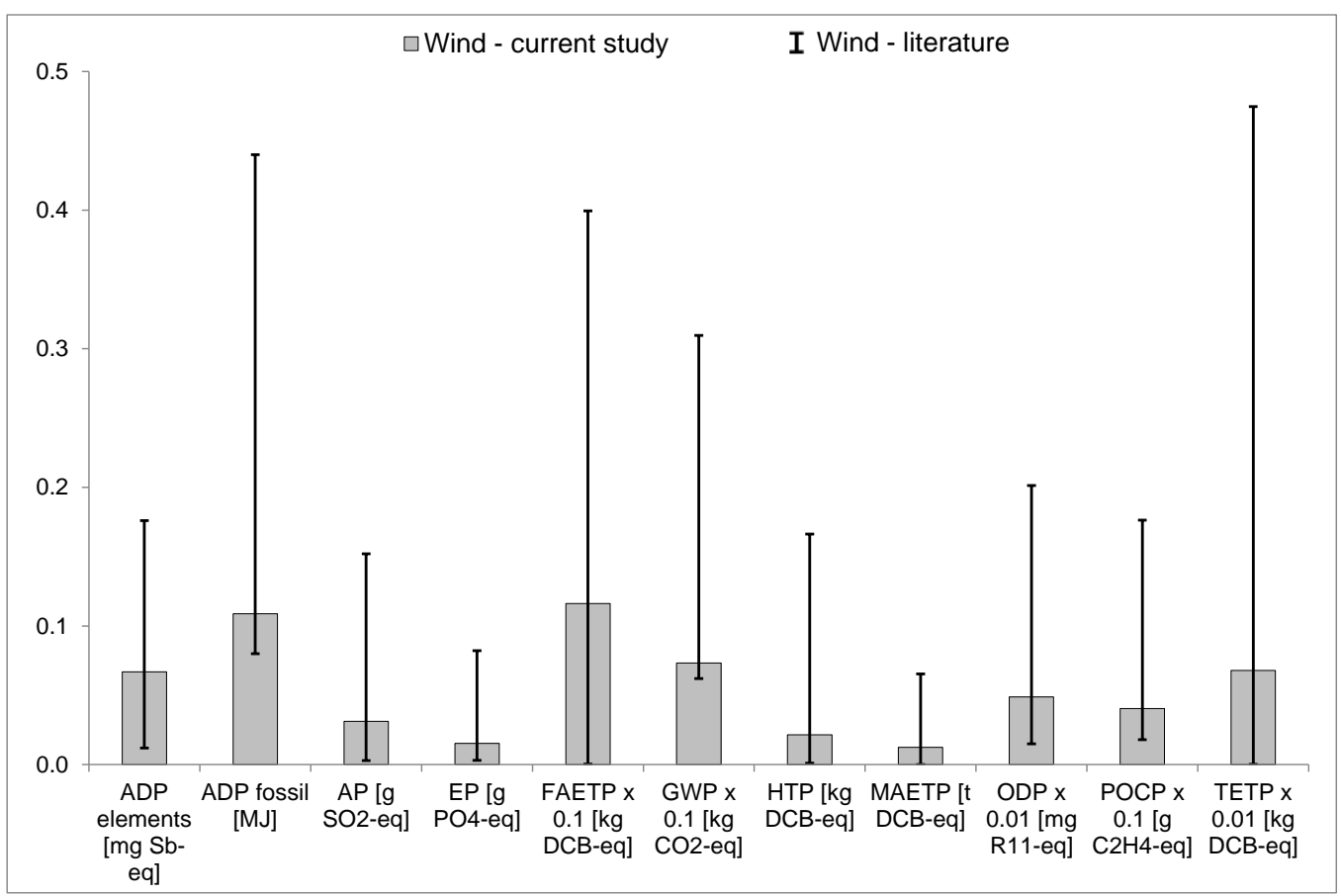

(b)

Figure 5. Comparison of the results from current study with literature for hydropower and wind power. (a) Reservoir and run-of-river hydropower. (b) Onshore wind. [All impacts expressed per kWh of electricity generated. The current study results for the reservoir hydropower present the average value for large and small reservoir. Literature data for reservoir from: [30,43,44]; for run-of-river from: $[20,23,26,29,43-45]$; for onshore wind from $[22,25,28,31,33,43]$. All impacts estimated using the CML 2001 method. For impacts nomenclature, see Figure 3.]. 


\subsection{Environmental Impacts of Electricity Generated in the Base Year}

Since the base year is used as a basis for the estimates of impacts in the other years, these results are discussed in more detail than for the rest of the period. Thus, the impacts for the base year are first presented for the functional unit of " $1 \mathrm{kWh}$ of electricity", followed by the "total annual generation of electricity".

\subsubsection{Impacts per $\mathrm{kWh}$}

The impacts per kWh of electricity generated in 2010 are given in Figure 6. The results suggest that fossil fuels cause the majority of the impacts, with coal contributing $43 \%-54 \%$ to the depletion of elements and fossil resources as well as the GWP; it also causes $84 \%-99 \%$ of the toxicity related impacts. The exception is ozone layer depletion, $98 \%$ of which arises from gas power.

These results are discussed for each impact in more detail below. Note that all the results incorporate the credits for material recycling after decommissioning of the plants.



Figure 6. Environmental impacts per $\mathrm{kWh}$ of electricity for the base year (2010). [For impacts nomenclature, see Figure 3.].

\section{Abiotic Depletion Potential}

The depletion of elements from electricity generation is estimated at $25.3 \mu \mathrm{g}$ Sb-eq. $/ \mathrm{kWh}$ (Figure 6). Lignite, hard coal and natural gas power contribute $14 \%, 29 \%$ and $46 \%$ to the total, respectively. The high contribution of hard coal, despite its small share in the electricity mix $(9.1 \%)$ is due to its long-range transport, which contributes $63 \%$ to the ADP of hard coal. By contrast, lignite is sourced domestically, so there are no impacts from transport.

The remaining contributions are from hydropower ( $8 \%$ ) and wind power $(4 \%)$; the impact from geothermal power is negligible $(0.1 \%)$. This impact is primarily due to the use of chromium, copper, molybdenum and nickel during the construction of the plants and fuel supply infrastructure. Coal and gas also account for the majority (99.9\%) of fossil resource depletion, equivalent to $8 \mathrm{MJ} / \mathrm{kWh}$ (Figure 6).

\section{Acidification and Eutrophication Potential}

The AP of $2.8 \mathrm{~g} \mathrm{SO}_{2}$-eq. $/ \mathrm{kWh}$ is mainly due to $\mathrm{SO}_{2}(82 \%)$ and $\mathrm{N}_{2} \mathrm{O}(14 \%)$ emissions. The biggest contributor is the electricity from lignite $(66 \%)$ because of the high sulphur content and a lack of desulphurisation systems at some of the plants. The second biggest contributor is hard coal power $(20 \%)$. 
Lignite is also the main cause of the $\mathrm{EP}$, estimated at $2.3 \mathrm{~g} \mathrm{PO}_{4}$-eq. $/ \mathrm{kWh}$, with the majority $(87 \%)$ related to the emissions of phosphates during mining. As for the $\mathrm{AP}$, the next biggest contributor is hard coal ( $9 \%)$.

\section{Ecotoxicity Potential}

All ecotoxicity related impacts (freshwater, marine and terrestrial) are also caused mainly by lignite power. For the FAETP, equivalent to $0.39 \mathrm{~kg}$ DCB-eq. $/ \mathrm{kWh}, 91 \%$ is due to the emissions of nickel, beryllium, cobalt and vanadium during mining. In the case of the MAETP, estimated at $1.2 \mathrm{t}$ DCB-eq. $/ \mathrm{kWh}$, the emissions to water of beryllium $(40 \%)$ and hydrogen fluoride to air $(33 \%)$ are the main burdens contributing to this impact. Finally, lignite contributes $66 \%$ to the TETP of $0.1 \mathrm{~g}$ DCB-eq. / $\mathrm{kWh}$, mainly because of the emissions of mercury $(\sim 75 \%)$.

\section{Global Warming Potential}

The global warming potential for the electricity mix in Turkey is estimated at $523 \mathrm{~g} \mathrm{CO}_{2}$-eq. $/ \mathrm{kWh}$. Emissions of $\mathrm{CO}_{2}$ account for $92 \%$ of the total, with $\mathrm{CH}_{4}$ contributing $7 \%$ and $\mathrm{N}_{2} \mathrm{O} 1 \%$. The main source of the GHG emissions is the combustion of coal and natural gas in power plants. The renewables contribute only $0.4 \%$ to the total GWP (Figure 6).

\section{Human Toxicity Potential}

Like ecotoxicity, this impact is also mainly due to lignite mining $(88 \%)$. The main burdens contributing to the HTP of $267 \mathrm{~g}$ DCB-eq. $/ \mathrm{kWh}$ include emissions of selenium (36\%) and hydrogen fluoride (11\%).

\section{Ozone Layer Depletion Potential}

The ODP is estimated at $45 \mu \mathrm{g}$ R11-eq. $/ \mathrm{kWh}$. The single largest contributor $(98 \%)$ is electricity from gas. As mentioned earlier, it is mainly due to leakages of halon 1211 and halon 1301 used as fire suppressants and coolants in the life cycle of gas.

\section{Photochemical Oxidants Creation Potential}

This impact is equal to $198 \mathrm{mg} \mathrm{C} \mathrm{C}_{2} \mathrm{H}_{4}$-eq./ $\mathrm{kWh}$ with $41 \%, 15 \%$ and $43 \%$ arising from lignite, hard coal and gas power plants, respectively. The main contributing burdens include $\mathrm{SO}_{2}(47 \%)$, non-methane volatile organic compounds $(32 \%)$ and $\mathrm{N}_{2} \mathrm{O}(11 \%)$.

\subsubsection{Total Annual Impacts}

As can be seen from Figure 7, lignite and hard coal power contribute together more than $40 \%$ to most of the impacts in the base year, despite providing only a quarter of the total electricity. The exception is ozone layer depletion which is almost entirely ( $98 \%)$ from gas power, which generates $46.5 \%$ of electricity. The renewables, which supply around $27 \%$ of the demand, add $0.04 \%-12 \%$ to the impacts, mainly related to hydropower because of its high share in the mix (24.5\%).

The total GWP is estimated at $111 \mathrm{Mt} \mathrm{CO}_{2}$-eq., $54 \%$ of which is due to coal and $46 \%$ to gas power. The estimated direct $\mathrm{CO}_{2}$ emissions (emitted from the power plants as opposed to the life cycle emissions) are equal to $92 \mathrm{Mt} \mathrm{CO}_{2}$-eq. This is in good agreement with the total direct emissions of $99 \mathrm{Mt} \mathrm{CO}_{2}$-eq. from the whole Turkish electricity sector in 2010 [11]. The slight difference between the two estimates stems from different assumptions, including plant efficiencies and the amount of fuel used in different power plants. 


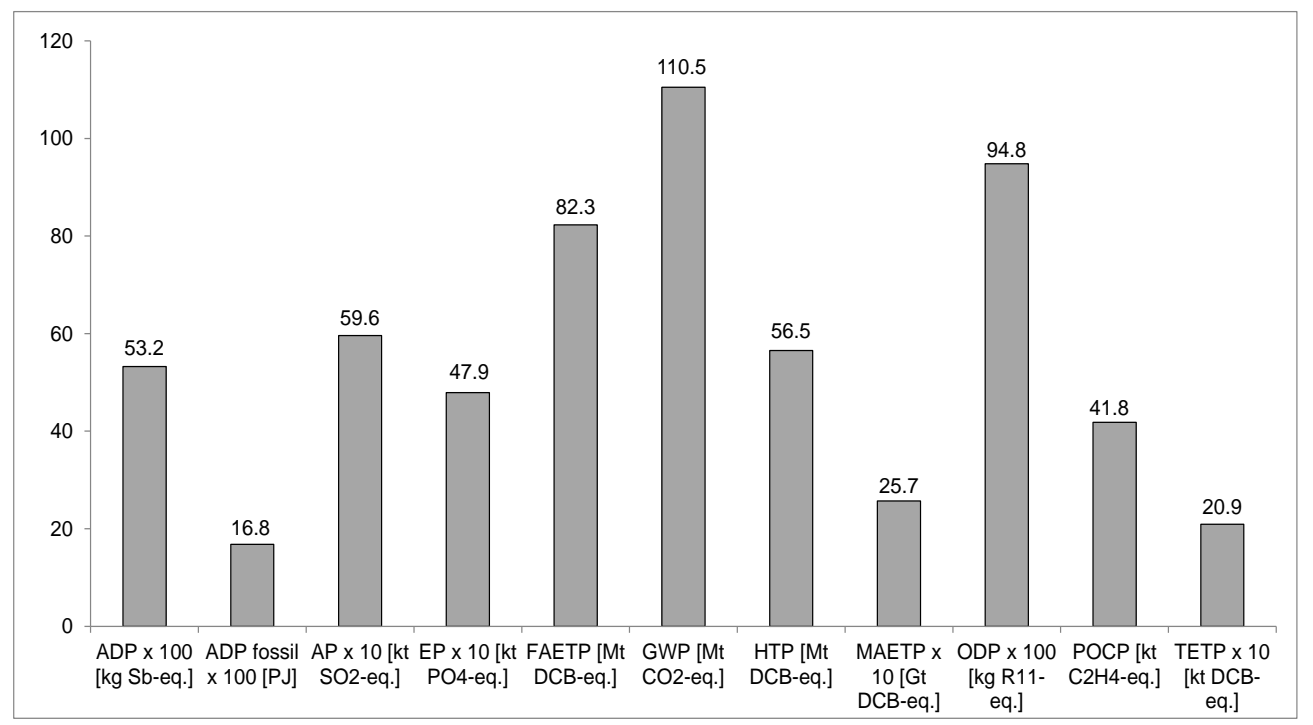

Figure 7. Total annual environmental impacts for the base year (2010). [For impacts nomenclature, see Figure 3.].

To put these results into context, they have been normalised to the annual impacts in the European Union comprising 28 countries (EU28). As indicated in Figure 8, Turkish electricity sector contributes almost $5 \%$ to the depletion of fossil fuels and $2 \%$ to the GWP relative to these impacts in the EU28 countries. The contribution to the AP, EP and POCP is also significant, ranging from $3.5 \%$ for the former to $2.4 \%$ for the latter. The contribution of the ADP elements and ODP is small (0.1\%). However, these results should be interpreted with care for at least two reasons: first, the base year for the EU28 impacts is 2000 (the latest available in the CML 2001 method) while the base year here is 2010; secondly, all impacts but the GWP for the EU28 are associated with high uncertainty and are likely underestimated, particularly the toxicity-related categories [46,47], which is the reason why they have not been considered in the normalised results.

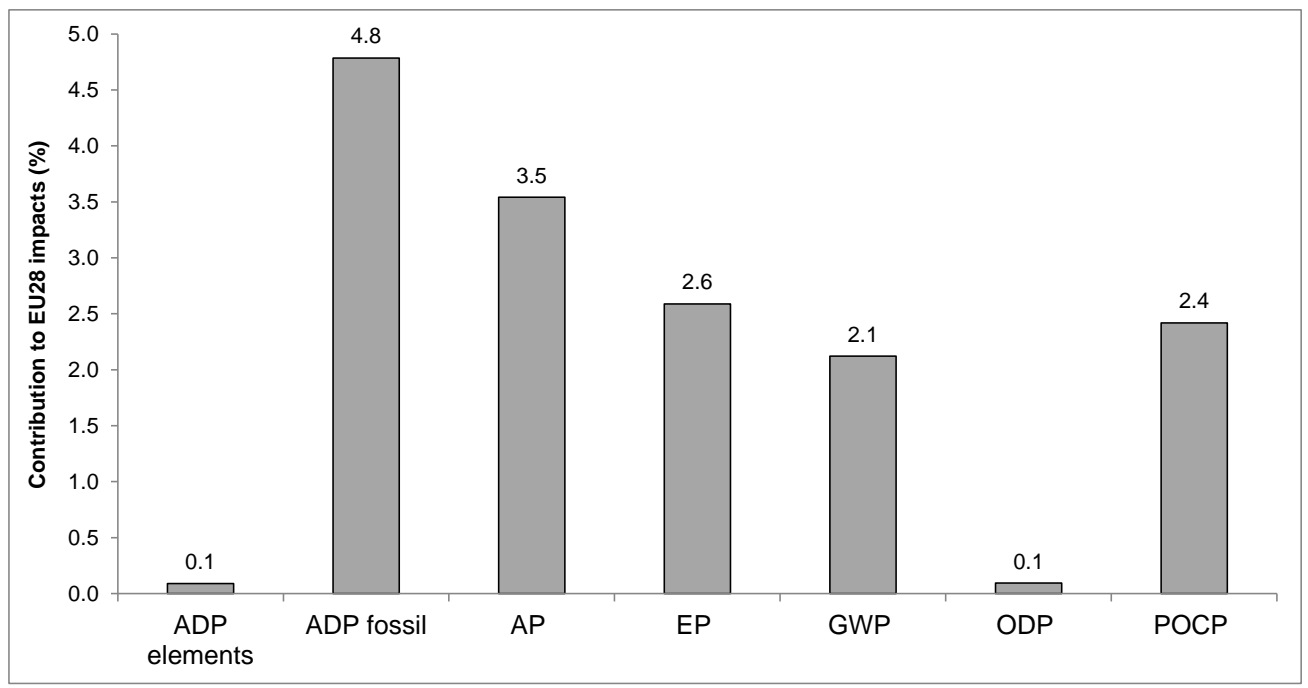

Figure 8. Annual impacts from electricity generation in Turkey in the base year (2010) normalised to the annual EU28 impacts. [EU28: the European Union with 28 countries. All data for the EU28 impacts are for the year 2000, the latest available data in the CML 2001 method. For impacts nomenclature, see Figure 3.]. 


\subsection{Environmental Impacts from Electricity Generation from 1990-2014}

The total annual environmental impacts from the electricity mix in Turkey over the period have been calculated based on the impacts of different technologies presented in Section 3.1, their contribution to electricity generation in a particular year and the total electricity generation in that year. The results are summarised in Figure 9; for brevity, they only show the impacts for selective years in five-year intervals: 1990, 1995, 2000, 2005, 2010 and 2014 (data for 2015 were not available at the time of writing).

Figure 9 also shows the generation mix for each of the years considered. In 1990, total generation was $57 \mathrm{TWh}$ and in 2014 it reached $250 \mathrm{TWh}$, representing a four-fold increase over the period. During this time, the electricity mix has also changed. In the past, it was mainly based on lignite, gas and reservoir hydropower but, over time, the contribution of other sources grew. For example, the share of hard coal (mainly imported) increased from 0.6 TWh in 1990 to 36.7 TWh in 2014. Since 2005, there has also been an increase in the share of renewables, mainly run-of-river hydropower (to $5 \%$ in 2014) and onshore wind (to 3\%). The reservoir hydropower generation was reduced by almost a half in 2000 compared to 1995 and by another half in 2014 compared to 2010 because of severe drought; the shortfall in electricity generation was made up by gas power.

It can be noticed from Figure 9 that the annual impacts have been going up steadily over the period, increasing from two times (EP, HTP, FAETP and MAETP) to nine-fold (ODP). The GWP increased by five-fold, from $28.7 \mathrm{Mt} \mathrm{CO}_{2}$-eq. in 1990 to $143 \mathrm{Mt} \mathrm{CO}_{2}$-eq. in 2014. This is largely due to a growing electricity demand, although for some impacts the rate of increase is higher than the demand growth, including the GWP, because of the higher rate of growth of fossil-fuel electricity. The only exception to the trend are the reductions in the EP, FAETP, HTP and MAETP in 2005 on the previous period as a result of a decrease in the share of lignite power. The latter, together with hard coal and gas dominate all the impacts because of their dominance in the generation mix, with coal providing $26 \%-35 \%$ and gas $18 \%-48 \%$ of electricity across the years.

The impact trends per $\mathrm{kWh}$ are less uniform than for the total annual impacts because they depend on the electricity mix only. On the other hand, the annual impacts also depend on the amount of electricity generated and increase proportionally to the demand. Although, in general, most impacts are higher for the fossil fuel options, some impacts are also high for the renewables (e.g., ADP for wind power; see Figure 3) so that their contribution to the total impacts from the electricity mix may be disproportionate to their share in the mix. The upward trend is found for four impacts: ADP elements and ODP, which are two times higher in 2014 than in 1990, and ADP fossil and GWP, which increased by $13 \%$ in the same period. The increase in the depletion of elements is due to the growth in renewable electricity generation because wind and hydropower have high resource requirements per $\mathrm{kWh}$ of electricity generated. The other three impacts have increased because of the increasing share of fossil fuels; for example, the share of gas increased from $25 \%$ in 1990 to $50 \%$ in 2014, leading to the significant increase in the ODP. Some impacts were also affected by the low hydropower generation during the drought in 2000 and 2014, with the GWP, ADP fossil, ODP and POCP having the highest values per $\mathrm{kWh}$ in these two years. For example, the GWP in 2000 was $550 \mathrm{~g} \mathrm{CO}_{2}$-eq. $/ \mathrm{kWh}, 13 \%$ higher than in 1995. In 2014, it was $570 \mathrm{~g} \mathrm{CO}_{2}$-eq. $/ \mathrm{kWh}$ or $8 \%$ higher than in 2010 , despite an overall $4 \%$ increase in the share of other renewables.

However, the opposite trend is found for the remaining impacts, with the EP, FAETP, HTP and MAETP being two times lower, the TETP 40\% and AP 34\% smaller at the end of the period than in 1990 . This is a result of the increase in natural gas and renewables in the mix. The only exception is the POCP, which remained more or less unchanged over the period. This is because of the cancelling effects of the change over time of the share of coal and gas in the mix and the difference in their respective POCP: lignite and hard coal have 1.8-2.7 times higher impact than gas but their contribution to power generation reduced by $20 \%$ from 1990 to 2014 while the contribution of gas doubled. 




Figure 9. Cont. 


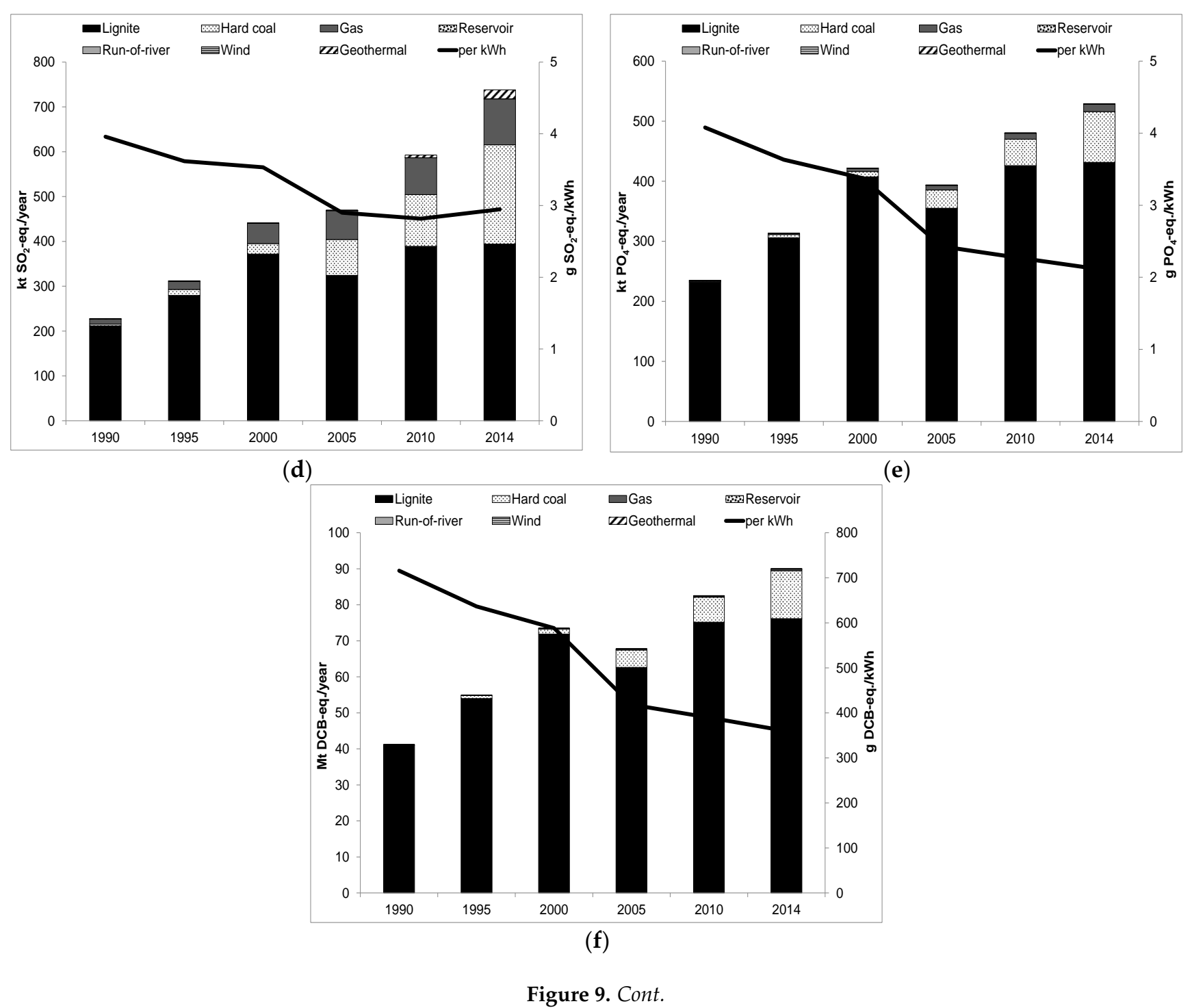



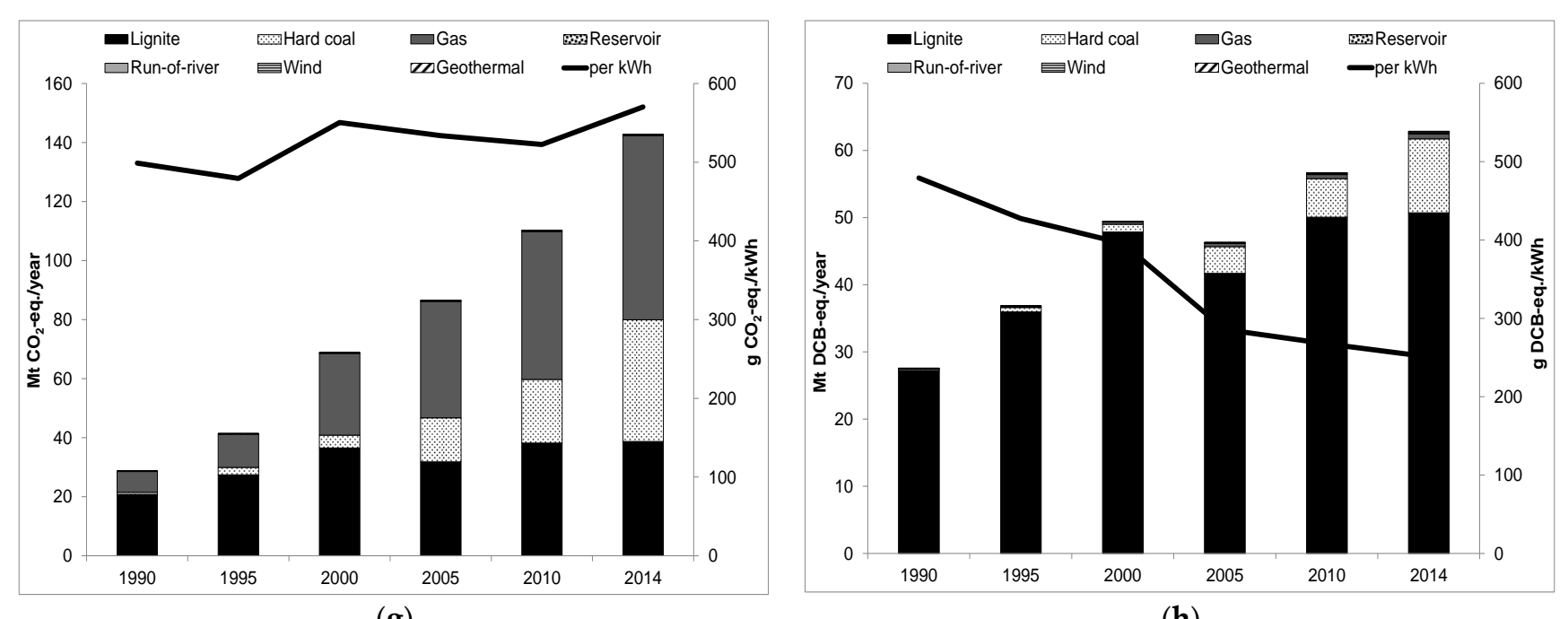

(g)

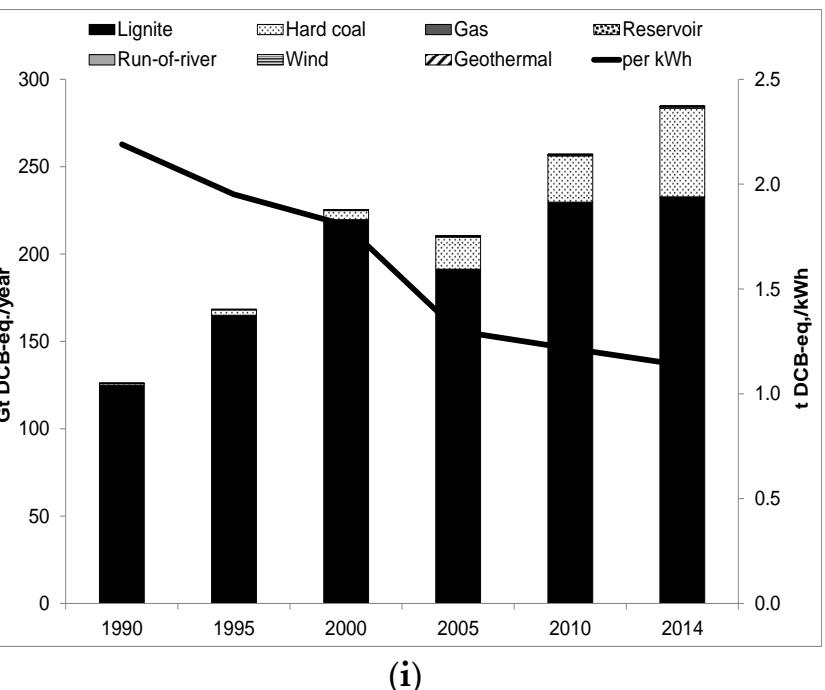

Figure 9. Cont. 


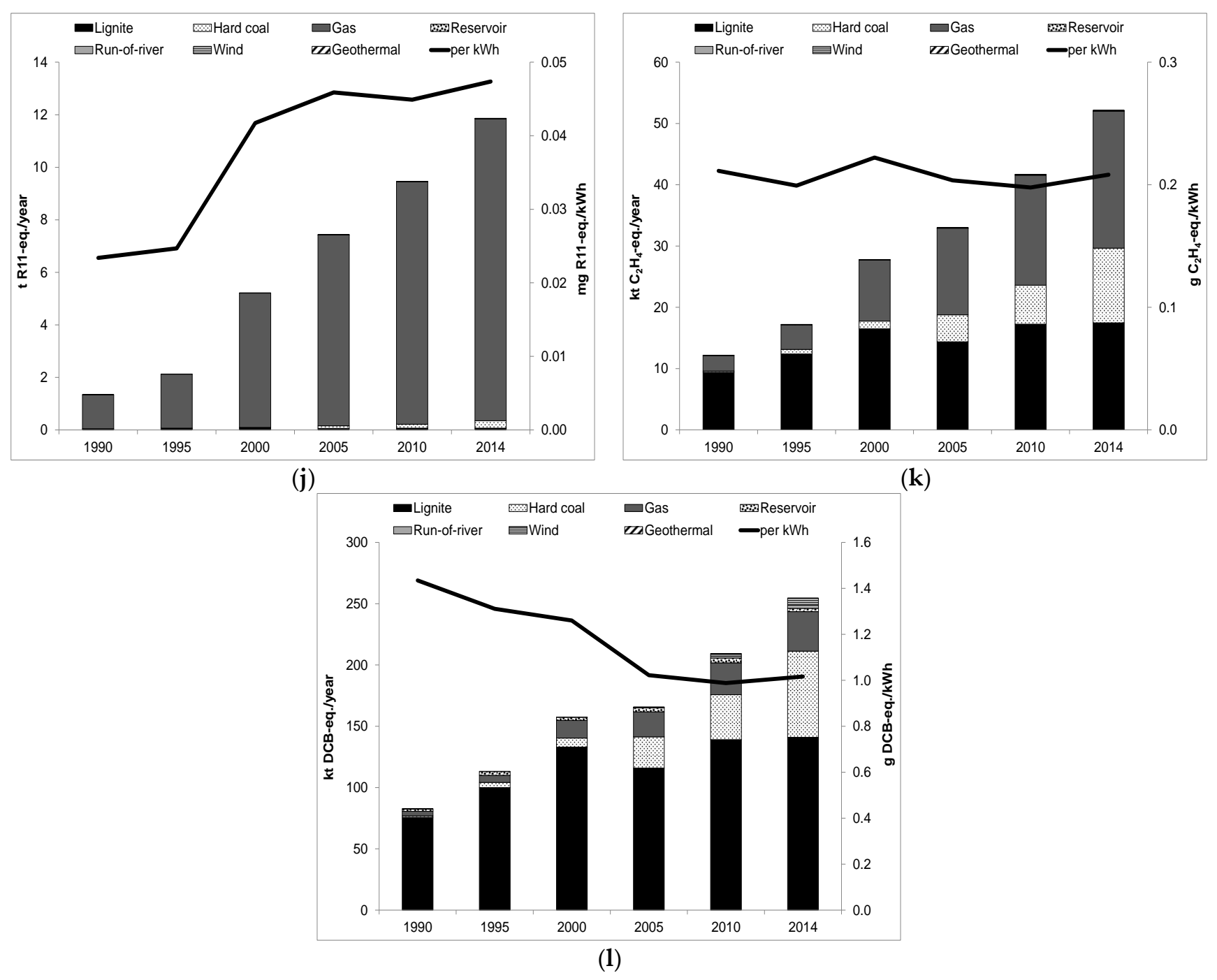

Figure 9. Environmental impacts of electricity in Turkey in the period 1990-2014 for total annual generation and per kWh. (a) Electricity generation mix in Turkey; (b) ADP elements; (c) ADP fossil; (d) AP; (e) EP; (f) FAETP; (g) GWP; (h) HTP; (i) MAETP; (j) ODP; (k) POCP; (1) TETP. [For impacts nomenclature, see Figure 3.]. 


\section{Conclusions}

This study has estimated for the first time the life cycle environmental impacts of electricity generation in Turkey for the period 1990-2014. Eleven impacts have been considered for 516 power plants using lignite, hard coal, natural gas, hydro (large and small scale reservoir hydro and run-of-river), onshore wind and geothermal energy. The impacts have been estimated per $\mathrm{kWh}$ and for the total amount of electricity generated annually over the period.

The results suggest that, in comparison to the other options, lignite power has the highest impacts for eight out of eleven categories. Gas power is the worst option for ozone layer depletion. Geothermal electricity scores the best for six impacts (eutrophication, ozone layer depletion and all the toxicity categories). Large-reservoir hydropower has the lowest depletion of elements and fossil resources as well as acidification. Run-of-river is the best option for the global warming potential.

The annual impacts have been going up steadily over the period, increasing from two times (EP, HTP, FAETP and MAETP) to nine-fold (ODP); the GWP increased by a factor of five. This is due to meeting the growing demand by fossil fuels. The trends per unit of electricity generated are less uniform than for the annual impacts. The upward trend is found for four impacts only: ADP elements and ODP, which are two times higher in 2014 than in 1990, and ADP fossil and GWP, which increased by $13 \%$ in the same period. However, the opposite trend is found for the other impacts, with the EP, FAETP, HTP and MAETP being two times lower, the TETP $40 \%$ and AP $34 \%$ smaller at the end of the period than in 1990. The only exception is the POCP, which remained more or less unchanged.

As a signatory to the Kyoto Protocol, it is important that Turkey identified more sustainable pathways for future electricity supply. Being a developing country, it is likely that the demand will continue to grow. Therefore, the key question is how to decouple the expected demand growth with the environmental impacts. The results of this work show that reducing the share of coal in the electricity mix would lead to significant reductions in GHG emissions as well as the other impacts such as acidification, eutrophication and all the toxicity categories. This could be achieved in the short term by expanding the natural gas capacity; however, both ozone layer depletion and energy dependency on other countries would increase. Given the great potential of renewable energies in Turkey, the expansion of renewables should be pursued more aggressively in the medium to long term. Among the renewable energy sources, hydro, onshore wind and geothermal power are well established in Turkey and have a large potential for development. However, increasing the proportion of onshore wind power in the electricity mix would increase depletion of elements while increasing the share of geothermal power would increase acidification. As the results show, hydropower options would lead to a reduction in the environmental impacts; however, that would be at the expense of some other impacts not included in this study, such as biodiversity and land use. Other renewables such as solar power could play a role in the future given that solar energy is abundant in Turkey. The country is also trying to introduce nuclear power, which would help to reduce GHG emissions, but it raises various other concerns, such as human health impacts from radiation, risk of accidents and long-term storage of nuclear waste.

The findings from this work have provided an insight into the previously unknown environmental impacts of electricity generation in Turkey, helping to identify opportunities for future improvements. However, in addition to the environmental sustainability evaluated here, it is also important to understand various economic and social aspects to help the industry and policy makers in Turkey identify and implement most sustainable electricity options for the future. This is the subject of a forthcoming paper by the authors.

Supplementary Materials: The following are available online at www.mdpi.com/1996-1073/9/1/31/s1.

Acknowledgments: This work was funded by the Republic of Turkey Ministry of National Education and the UK Engineering and Physical Sciences Research Council, EPSRC (Grant no. EP/K011820/1). This funding is gratefully acknowledged.

Author Contributions: Adisa Azapagic conceived and supervised the research. Burcin Atilgan collected the data and carried out the LCA study. Adisa Azapagic and Burcin Atilgan co-wrote the paper. 
Conflicts of Interest: The authors declare no conflict of interest.

\section{References}

1. MENR. Mavi Kitap (Blue Book); Ministry of Energy and Natural Resources: Ankara, Turkey, 2012; pp. 20-69.

2. WEC. Turkey Energy Balance Table (1970-2004). Available online: http://www.dektmk.org.tr/incele. php?id=MTQ3 (accessed on 13 April 2014).

3. TEIAS. Electricity Generation \& Transmission Statistics of Turkey. Available online: http://www.teias.gov.tr/ TurkiyeElektrikIstatistikleri.aspx (accessed on 2 June 2014).

4. EUAS. Annual Report; Turkish Electricity Generation Company (EUAS): Ankara, Turkey, 2011.

5. TPAO. The Oil and Gas Sector Report of Turkey; Turkish Petroleum Corporation (TPAO): Ankara, Turkey, 2011; pp. 1-26.

6. MMO. Turkiye'de Termik Santraller; Makina Muhendisleri Odasi: Ankara, Turkey, 2010; pp. 1-81.

7. TKI. Lignite Sector Report of Turkey; General Directorate of Turkish Coal Enterprises (TKI): Ankara, Turkey, 2012; pp. 1-61.

8. DSI, Turkey Water Report 2009. Available online: http://www2.dsi.gov.tr/english/pdf_files/TurkeyWater Report.pdf (accessed on 20 March 2012).

9. EMRA. Data on Energy Potential of Turkey; Personel communication, 15.06.2014; Republic of Turkey Energy Market Regulatory Authority: Ankara, Turkey, 2014.

10. Komurcu, M.I.; Akpinar, A. Importance of geothermal energy and its environmental effects in Turkey. Renew. Energy 2009, 34, 1611-1615. [CrossRef]

11. FutureCamp. Baseline Emission Calculations, Verified Carbon Standard (VCS); Version 3; FutureCamp: Ankara, Turkey, 2011.

12. Atilgan, B.; Azapagic, A. Life cycle environmental impacts of electricity from fossil fuels in Turkey. J. Clean. Prod. 2015, 106, 555-564. [CrossRef]

13. Atilgan, B.; Azapagic, A. Renewable electricity in Turkey: Life cycle environmental impacts. Renew. Energy 2015. in press. [CrossRef]

14. Kannan, R.; Leong, K.C.; Osman, R.; Ho, H.K.; Tso, C.P. Gas fired combined cycle plant in Singapore: Energy use, GWP and cost and Life cycle approach. Energy Convers. Manag. 2005, 46, 2145-2157. [CrossRef]

15. Weisser, D. A guide to life-cycle greenhouse gas (GHG) emissions from electric supply technologies. Energy 2007, 32, 1543-1559. [CrossRef]

16. Guinée, J.B.; Gorrée, M.; Heijungs, R.; Huppes, G.; Kleijn, R.; Koning, A. Life Cycle Assessment: An Operational Guide to the ISO Standards: Part 2a; Ministry of Housing, Spatial Planning and Environment (VROM) and Centre of Environmental Science (CML): Den Haag and Leiden, The Netherlands, 2001.

17. International Standard Organization (ISO). Life Cycle Assessment-Requirements and Guidelines; ISO: Geneva, Switzerland, 2006.

18. International Standard Organization (ISO). Life Cycle Assessment_Principles and Framework; ISO: Geneva, Switzerland, 2006.

19. PE International. GaBi version 6; PE International: Stuttgart, Echterdingen, Germany, 2013.

20. Schuller, O.; Albrecht, S. Setting up Life Cycle Models for the Environmental Analysis of Hydropower Generation, Considering Technical and Climatic Boundary Conditions; Life Cycle Assessment VIII: Seattle, WA, USA, 2008.

21. Pehnt, M.; Henkel, J. Life cycle assessment of carbondioxide capture and storage from lignite power plants. Int. J. Greenh. Gas Control 2009, 3, 49-66. [CrossRef]

22. Martínez, E.; Sanz, F.; Pellegrini, S.; Jiménez, E.; Blanco, J. Life-cycle assessment of a 2 MW rated power wind turbine: CML method. Int. J. Life Cycle Assess. 2009, 14, 52-63. [CrossRef]

23. Suwanit, W.; Gheewala, S. Life cycle assessment of mini-hydropower plants in Thailand. Int. J. Life Cycle Assess. 2011, 16, 849-858. [CrossRef]

24. Santoyo-Castelazo, E.; Gujba, H.; Azapagic, A. Life cycle assessment of electricity generation in Mexico. Energy 2011, 36, 1488-1499. [CrossRef]

25. Lahuerta, F.; Saenz, E. Life cycle assessment of the wind turbines installed in Spain until 2008. In Proceedings of the Europe's Premier Wind Energy Conference and Exhibition, Brussels, Belgium, 14-17 March 2011.

26. Pascale, A.; Urmee, T.; Moore, A. Life cycle assessment of a community hydroelectric power system in rural Thailand. Renew. Energy 2011, 36, 2799-2808. [CrossRef] 
27. Stamford, L.; Azapagic, A. Life cycle sustainability assessment of electricity options for the UK. Int. J. Energy Res. 2012, 36, 1263-1290. [CrossRef]

28. Pereg, J.R.M.; Hoz, J.F. Life Cycle Assessment of 1 kWh Generated by a Gamesa Onshore Windfarm G90 2.0 MW; Gamesa: Zamudio (Vizcaya), Spain, 2013.

29. Arnøy, S.; Modahl, I.S. Life Cycle data for Hydroelectric Generation at Embretsfoss 4 (E4) Power Station: Background Data for Life Cycle Assessment (LCA) and Environmental Product Declaration (EPD); Ostfold Research: Kråkerøy, Norway, 2013.

30. Arnøy, S. Hydroelectricity from Trollheim Power Station; Østfoldforskning AS: Oslo, Norway, 2013.

31. Garrett, P.; Rønde, K. Life Cycle Assessment of Electricity Production from an Onshore V90-3.0 MW Wind Plant; Vestas Wind Systems A/S: Aarhus, Denmark, 2013.

32. Garrett, P.; Rønde, K. Life cycle assessment of wind power: Comprehensive results from a state-of-the-art approach. Int. J. Life Cycle Assess. 2013, 18, 37-48. [CrossRef]

33. Palomo, B.; Gaillardon, B. Life Cycle Assessment of a French Wind Plant; Europe's Premier Wind Energy Event: Barcelona, Spain, 2014.

34. IEA/NEA. Projected Costs of Generating Electricity, 2005 Update; International Energy Agency and Nuclear Energy Agency: Paris, France, 2005.

35. Aslanoglu, S.Y.; Koksal, M.A. Elektrik uretimine bagli karbondioksit emisyonunun bolgesel olarak belirlenmesi ve uzun donem tahmini. Hava Kirliligi Arastirma Derg. (HKAD) 2012, 1, 19-29.

36. Öko Institute Global Emission Model for Integrated Systems (GEMIS) v.4.8. Available online: http://www.oeko.de/service/gemis/en/index.htm (accessed on 10 September 2012).

37. Dones, R.; Bauer, C.; Bolliger, R.; Burger, B.; Faist Emmenegger, M.; Frischknecht, R.; Heck, T.; Jungbluth, N.; Röder, A.; Tuchschmid, M.; et al. Ecoinvent Report: Life Cycle Inventories of Energy Systems: Results for Current Systems in Switzerland and Other UCTE Countries; Swiss Centre for Life Cycle Inventories: Dübendorf, Switzerland, 2007.

38. Bauer, C.; Bolliger, R. Ecoinvent Report: Wasserkraft; Swiss Centre for Life Cycle Inventories: Dübendorf, Switzerland, 2007.

39. Flury, K.; Frischknecht, R. Life Cycle Inventories of Hydroelectric Power Generation, ESU Database; Öko-Institute e.V.: Uster, Switzerland, 2012.

40. Coulson, J.M.; Sinnott, R.K.; Richardson, J.F. Coulson E Richardson's Chemical Engineering; Butterworth Heinemann Ltd.: Oxford, UK; Boston, MA, USA, 1993.

41. Kouloumpis, V.; Stamford, L.; Azapagic, A. Decarbonising electricity supply: Is climate change mitigation going to be carried out at the expense of other environmental impacts? Sustain. Prod. Consum. 2015, 1, 1-21. [CrossRef]

42. TEIAS. Turkiye Elektrik Enerjisi Uretim Planlama Calismasi (2012-2030); Turkish Electricity Transmission Corporation (TEIAS), Research Planning and Coordination Department: Ankara, Turkey, 2013.

43. Swiss Centre for Life Cycle Inventories. Ecoinvent, Ecoinvent Database v2.2; Swiss Centre for Life Cycle Inventories: St. Gallen, Switzerland, 2010.

44. ESU. ESU Database; Öko-Institute e.V., ESU-services Ltd.: Uster, Switzerland, 2012.

45. Raadal, H.L.; Gagnon, L.; Modahl, I.S.; Hanssen, O.J. Life cycle greenhouse gas (GHG) emissions from the generation of wind and hydro power. Renew. Sustain. Energy Rev. 2011, 15, 3417-3422. [CrossRef]

46. Benini, L.; Mancini, L.; Sala, S.; Manfredi, S.; Schau, E.M.; Pant, R. Normalisation Method and Data for Environmental Footprints; European Commission, Joint Research Centre, Institute for Environment and Sustainability: Ispra, Italy, 2014.

47. Heijungs, R.; de Koning, A.; Lightart, T.; Korenromp, R. Improvement of LCA Characterisation Factors and LCA Practice for Metals; TNO Environment, Energy and Process Innovation, Netherlands Organisation for Applied Scientific Research: Apeldoorn, The Nertherland, 2004.

(C) 2016 by the authors; licensee MDPI, Basel, Switzerland. This article is an open access article distributed under the terms and conditions of the Creative Commons by Attribution (CC-BY) license (http://creativecommons.org/licenses/by/4.0/). 